\title{
Game Analysis on Anti-leak Contract Signing*
}

\author{
Xiuli Tan, Zhongquan Chen, Jihong Cheng \\ Business College, Yantai Nanshan University, Yantai, China
}

\begin{abstract}
This dissertation carries out analysis on strategic actions taken by signing parties to prevent business secrete leakage, using basic principle of game theory. Expansion definition on protecting scope of business secret is given; convention on high breach penalty; appropriate enlargement on compensation amount etc. Research results have reference value to strategy selection on business secret for contract signing parties.
\end{abstract}

Index Terms - Game; business secret; secret leakage; contract clauses; contract signing

\section{Introduction}

According to article ten in Law of the People's Republic of China for Countering Unfair Competition, business secret refers to: Technical information and operation information which are unknown to the public, able to bring about economic benefits to the obligee, with practicability and protected via taking security measures. From this, it could be known that components of business secrete include the following three elements: Confidentiality, value and security measures taken by the obligee.

For legal attribute of business secret, there're three concepts among scholars. First is the early property right. This theory regards business secret as an intangible property. [1]With four major powers and functions of ownership, economic value of business secret has achieved recognition of the society, however, what is being doubted is that as a property right, it possesses no exclusiveness and right in rem; second is the human right theory. It regards infringement on business secret is that on personality benefits. [2] However, what is doubted is that its suitability is closely irrelevant to specific obligee, making it unable to carry out business operation; third is the intelligence property right theory. It deems business secret shall be treated as a special intelligence property right. [3] This is the mainstream concept in China's academic circle at present. This theory does not only comply with actual need to protect business secret, but accords with the international developing trend of intelligence property right protection. The author thinks that adopting the intelligence property right theory will do good to protecting legal interests and rights of both signing parties, while connect to international intelligence property right conventions, so it is more considerate and appropriate for preventing the leakage of business secret and protecting business secret.

During signing the contract, to avoid the leakage of business secret, is a primary issue to be considered by both parties of the contract. In this essay, basic principle of the game theory is utilized, to carry out analysis on signing strategies adopted by both parties respectively, so as to provide reference for both parties to protect its own legal rights and interests to the greatest extent.[4]

\section{Game Analysis on Both Parties}

Assumed that in a business contract, Party A possesses one business secret, during contract signing between both parties, Party A needs to disclose such business secret to Party B, if both Party A and Party B have reached an agreement and signed a contract, both parties are certain to adopt effective measures to protect such business secret. However, if no agreement has been achieved between Party A and Party B, Party B shall keep secret for Party A, otherwise, Party A shall have the right to suit Party B's impacting its own legal rights and interests and to obtain economic compensation. Now assumed that there's no agreement achieved between Party A and Party B, and both parties will carry out a game focusing on keeping Party A's business secret. [5]It is regulated that a represents economic compensation to be undertaken by Party $\mathrm{B}$, after losing a lawsuit because of secret leakage; $b$ represents other lawsuit costs except for Party A's lawsuit fee; $C$ represents benefits obtained by Party B for disclosing Party A's business secret; $d$ represents other costs of Party B to fight Party A's lawsuit except for lawsuit fee; ${ }^{e}$ represents economic compensation to be undertaken by Party A if it loses the lawsuit; $m_{1}$ represent lawsuit fee of Party $\mathrm{A} ; m_{2}$ represents lawsuit fee of Party B; the probability of Party B's disclosing Party A's business secret is y, while the probability of Party A to take Party B to court is $\mathrm{x}$.

$\mathrm{G}$ represents economic loss of Party A caused by Party B's secret leakage;

Payment matrix for the game between Party A and Party $\mathrm{B}$ is as follows:

\footnotetext{
* Funds project: This dissertation is a periodic achievement of 2014 Yantai Nanshan Academy Research Fund for Young Teachers - Based on Logistics Finance Mode for Regional Economic Development and Risk Management Research [201408];

Subject project: This dissertation is a periodic achievement of 2014 Yantai Social Science Planning Research Project - Research on Yantai Supply Chain

Financial Ecological Environment Optimization [YTSK-028].
} 
Table 1. Payment Matrix for the Game between Party A and Party B

\begin{tabular}{|l|l|l|}
\hline & $\begin{array}{l}\text { Party B discloses } \\
\text { Party A's } \\
\text { business secret } \\
\text { (Probability is y) }\end{array}$ & $\begin{array}{l}\text { Party B does not } \\
\text { disclose Party A's } \\
\text { business secret } \\
\text { (Probability is 1-y) }\end{array}$ \\
\hline $\begin{array}{l}\text { Party A takes Party } \\
\text { B to court } \\
\text { (Probability is } x)\end{array}$ & $\begin{array}{l}(a-b \\
c-d-a-n\end{array}$ & $\begin{array}{l}( \\
-b-e-m_{1}-n\end{array}$ \\
\hline $\begin{array}{l}\text { Party A does not } \\
\text { take Party B to court } \\
\text { (Probability is }\end{array}$ & $(\mathrm{g}, c)$ & $(0,0)$ \\
\begin{tabular}{l}
$1-x)$ \\
\hline
\end{tabular} & & \\
\hline
\end{tabular}

Max. benefits expected by Party A and Party B are as follows respectively:

$E_{A}=\mathrm{x}\left[y(a-b)+(1-y)\left(-b-e-m_{1}-m_{2}\right)\right]+(1-x)[\mathrm{y}(-a)+(1-y) 0]$

$E_{B}=y\left[x\left(c-d-a-m_{1}\right)+(1-\mathrm{x}) c\right]+(1-y)[x(-d+e)+(1-x) 0]$

Provided that

$$
\frac{\partial \boldsymbol{E}_{A}}{\partial \mathrm{x}}=\mathbf{O}, \frac{\partial \boldsymbol{E}_{B}}{\partial y}=\mathbf{O}
$$

So the Nash equilibrium for the combined strategy for the game between both parties is obtained:

$$
\left(x^{*}, y^{*}\right)=\left(\frac{c}{a+m_{1}+e}, \frac{b+e+m_{1}+m_{2}}{a+\mathrm{g}+e+m_{1}+m_{2}}\right)
$$

\section{A. Game Analysis on Terms on Secret Keeping Scope When Costs Other Than Party A's Lawsuit Fee is High}

From equation (1), it could be known that $\mathrm{y}^{*}$ is an increasing function of $\mathrm{b}$. So when Party $\mathrm{A}$ decides to take Party B to court, lawsuit costs other than lawsuit fee to be paid by Party A will be higher, which means Party A's probability of disclosing secrete will increase with that in Party A's lawsuit costs other than lawsuit fee.

For higher lawsuit costs other than Party A's lawsuit fee, means Party A needs to spend more money, energy and time, in order to keep its vested economic benefits, the possibility for Party A to abandon taking Party B to court will become larger, while the probability is the measurement on the occurrence of random secret leakage. Party A suggests itself or prays for itself that Party B will not disclose secret subconsciously, and Party A's attitude is constantly static; however, as for Party B, secret leakage is alluring, while the myth of becoming rich overnight may come true, with Party B's attempt to disclose, so Party A's attitude becomes a key point for Party B's research. Via various phenomena, Party B deducts that, the possibility of Party A to take it to court is very slim, for high lawsuit costs other than lawsuit fee, while thinks its disclosure of secret will be safe, and make a reckless move to disclose. So lawsuit costs other than Party A's lawsuit fee have decided the probability of Party B's disclosure of business secret.

In this case, for the increase in lawsuit costs other than Party A's lawsuit fee, it will cause the increase in the probability of Party B's disclosure of business secret, and there will be different strategies between both parties during actual signing process [6]

(1) Party B's selection on the strategy of reducing secretkeeping scope

During signing the contract, if Party B expects to obtain benefits via disclosing business secret, it will try to increase lawsuit costs other than Party A's lawsuit fee via setting various barriers. [7]Party $B$ will regard reducing secretkeeping scope as its contract signing strategy, and prepare contract terms with secret-keeping scope less than or limited to the listed scope, i.e. general secret-keeping scope in Business Cooperation Confidentiality Agreement is listed as customer name list and name card, list of potential customers being contacted, phone contact list, price information, price and quotation method information, financial situation and anticipation information, trading information, manufacturing technology, information involved in sales amount and benefits, product development technology and development plan, business strategies, procedures, market strategies, marketing methods and training materials, as well as evidence materials such as information involved in customers of either party or associated enterprises etc.

Party B tries to reduce confidentiality items via contract signing, so as to reach the purpose of disclosing business secret without breaching the contract. It will be useless even if Party A taking it to court after that, for there's no definite regulation on disclosure items in confidentiality terms, nor any legal evidence for protection. So both Party A and Party B will enter a dilemma, while any party bringing an accusation against the other will only increase its lawsuit costs, and undertake the results because of losing the lawsuit; otherwise, Party B's disclosure behavior will be indulged which will then infringe its own legal interests and rights.

(2)Party A's selection on the strategy of enlarging secretkeeping scope

In order to prevent Party B's breaching of the contract and disclosing business secret, Party A will also try all means to reduce lawsuit costs other than its own lawsuit fee. i.e.: Party A enlarges the scope of secret-keeping materials during contract signing, for example, those listed in the above Business Cooperation Confidentiality Agreement, generally, Party A will decide the scope of confidentiality materials including but not limited to those listed during contract signing, and will increase the extension of confidentiality materials, i.e.: This "confidentiality material" could be business secret complying with regulations of the law, or other confidentiality materials not reaching conditions of business secret regulated by law.

Under the restriction of terms of this contract, the probability for Party B to disclose reduces. For disclosure of secret means over high lawsuit costs other than Party B's 
lawsuit fee. Once disclosure of secret occurs, and Party A takes it to court, with expressive regulations in contract terms for confidentiality scope, and the fact of infringement on rights, Party $\mathrm{B}$ is destined to undertake legal results of losing the lawsuit. However, economic compensation is what Party B cares about. In addition, Party A could also adopt additional measures to protect business secret. i.e. encrypting evidence using high-tech methods in advance; adopting monitoring to avoid others from entering physical regions with secret, or asking for a lawyer to interfere ahead of schedule, to protect business secret etc., which will not be discussed in this dissertation.

\section{B. Game analysis on terms about high breaching penalty for} Party B's disclosure of secret

From equation (1), it could be seen that $\mathrm{y}^{*}$ is a decrease function of a. When Party B discloses secret, and Party A decides to take it to court, if the court judges Party A to win, greater economic compensation to be undertaken by Party B to Party A, will make Party B be more cautious, and not that easy to disclose. When Party B discloses secret, if Party A does not take Party B to court, greater loss undertaken by Party A probably makes greater benefits to be gained by Party $\mathrm{B}$, and Party B will be more inclined to make the decision to disclose. So when both parties sign a contract, Party A could prepare terms, so that when Party B disclose secret, it will pay a high penalty for breaching of the contract. At this time, signing parties will select different strategies:

(1) Party B's selection on the strategy of abandoning secret disclosure

Under the threat of high penalty of breaching of the contract, it is equal to declare to Party B that: If Party B disclose, it will bring about huge loss to Party A, and Party A will warn it to keep business secret, otherwise, it will undertake huge penalty for breaching the contract. Party B will calculate the difference between costs and benefits for disclosure, and decide whether to disclose with caution. Generally, under the pressure of huge penalty for breaching the contract, Party B will abandon disclosure of secret.

(2) Party A's selection on the strategy of taking to court

After setting the term of high penalty for breaching the contract, if Party B is a desperado and selects disclosure of secret, the made term of penalty for breaching the contract, while Party A decides not to take to court, Party B will gain great benefits, and Party A will be subject to loss. Generally, Party A will not sit passively for its end, but fight for itself. The legal result generated by setting a high breach of contract is that: Under the condition that Party B discloses, A decides to take it to court, and the court judges Party A to win, if the economic compensation to be undertaken by Party B to Party A, is greater than Party B's disclosure of secret, Party A will be subject to loss if it does not take Party B to court.

For economic compensation includes penalty for breaching of the contract, Party A's loss does not contain the penalty. In this way, once Party B discloses, Party A will change to take it to court, and Party B will face more compensation. At this time, it will cause greater threat to Party
B, making it keep secret, and enhancing Party A's decision to take it to court. In addition, it could also be regulated that, if Party B discloses, and Party A takes it to court, the attorney fee, lawsuit fee and other expenses for collecting evidence will be undertaken by Party B. This further enhances the burden for Party B's losing the lawsuit, making it dare not to disclose.

\section{Game analysis on terms about confidentiality scope when} the benefit for Party B's disclosure is huge

From equation (1), it could be seen that, $x^{*}$ is an increase function of c, so it is known that: The greater benefits obtained by Party B for its disclosing Party A's business secret, the probability of Party A's deciding to take Party B to court will be larger. Generally, in the same time and space, when market capacity is limited, market share for Party B's disclosing product or product disclosed to a third party will be greater, benefits gained by Party B or the third party will be larger, while the loss of Party A because of its market being occupied by force will be greater. So when signing a contract, Party A will select the strategy of enlarging project confidentiality scope. Party A will take cautions to study all circles which may be subject to disclosure of business secret in related projects under discussion, which is to enlarge confidentiality scope of the project to the greatest extent, while related specifications are contained in the contract. For example, it is regulated in the Project Cooperation Confidentiality Agreement that: Business secrets mentioned in this contract, including but not limited to: Technical plans, engineering design, circuit design, manufacturing methods, formulas, technique process, technical index, computer software, database, research \& development records, technical reports, test reports, test data, test results, drawings, samples, sample machines, models, tools, operation manuals, technical documents, related business correspondences etc. Other business secrets mentioned in this contract, include but not limited to: Customer list, marketing plan, purchase information, pricing policy, financial materials, and purchase channels etc.

During contract negotiation, Party B will select the strategy of reducing project confidentiality scope, purpose of which is good for disclosure of secret while Party A is unable to win and obtain compensation. The reasons are explained in the above IV (I) 1, which will not be reiterated herein.

\section{$D$. Game analysis on high penalty for breaching the contract when the compensation for Party B's disclosure is huge}

From equation (1), it could be seen that, $x^{*}$ is a decrease

function of a, e and $\boldsymbol{m}_{1}$. Under the condition that Party B discloses, and Party A decides to take it to court, if the court judges Party A to win, greater economic compensation to be undertaken by Party B to Party A, Party B will be more cautious, and not that easy to make a decision to disclose, while Party A will be more inclined to take it to court. It is coincided with the above IV(II)2 that, during the preparation of contract terms, it is required to consider economic value of the project under discussion, as well as once Party B discloses, 
to reasonably determine Party B's compensation amount to Party A according to benefits obtained by Party B and Party A's losses, while both parties could be restricted by the above additional contract terms about high breach penalty, so as to reduce Party B's breaching of the contract, and Party A's lawsuit.

\section{E. Game analysis when Party A will be subject to huge compensation if Party $B$ does not disclose}

Under the condition that Party B does not disclose, if Party A takes Party B to court, it will lose, so Party A will undertake greater economic loss for losing the lawsuit, while the probability of Party A to prosecute will be smaller. According to this, when signing a contract, great importance shall be attached to economic loss undertaken by Party A for its error, while increasing compensation amount appropriately, will be good for enhancing the contract's effect and stability.

In addition, according to related laws and regulations, the greater lawsuit fee of Party A, makes smaller probability for Party A to prosecute. Although, the lawsuit fee is an expense generated by the project being signed, and is not within the restriction of contract terms, from the above analysis, we could know that higher lawsuit fee will make smaller probability of Party A's taking Party B to court. However, it will also make the probability of Party B's motivation of disclosing Party A's business secret increase. But there's exception either, Party B is not certain to disclose Party A's business secret, this is because Party B's disclosure of Party A's business secret is also restricted by other factors, however, this will not be discussed herein.

\section{Conclusions}

Under mixed strategy Nash equilibrium, it is regulated to prevent the disclosure of business secret by contract terms, and the following issues shall be noted:

(1) It is required to define and enlarge confidentiality scope to the greatest extent in the contract's confidentiality terms, purpose of which is when any disclosure occurs, there's related evidence for claiming, so as to reduce Party B's disclosure of secret and Party A's prosecution.

(2) It is regulated in contract terms that: If any breach of contract occurs, any party shall undertake a high penalty for breaching the contract, to prevent Party B from disclosing, and to make Party A's secret-keeping behaviors within effective scope of contract terms.

(3) It is regulated in contract terms that: If Party B discloses, the amount of compensation to be obtained by Party A via prosecuting or Party B does not disclose, while Party A prosecutes, the amount of compensation to be obtained by Party B shall be enlarged accordingly, this will benefit to enhance effectiveness and stability of the contract.

In a word, Under mixed strategy Nash equilibrium, the purpose of making contract terms about preventing disclosure of business secret is to reduce Party B's breaching of the contract by disclosure, and Party A's prosecuting, to enhance the contract's effectiveness and stability, so that the whole nation, society and family could reach harmony and stability, thus to seek for development, innovation and respect on intelligence property right.

\section{References}

[1] Kong Xiangjun Business Secret Protection Law Theory. Beijing: China Legal Publishing House, 1999:155.

[2] Wu Handong. Private Right of Intelligence Property Right and Human Right Attributes. Jurisprudential Study, 2003, (3): 45.

[3] Sun Xiangjun. Wu Jianying. Liu Zeyu. WTO Rules and China's Intelligence Property Right Law. Tsinghua University Press, 2008: 232.

[4] David. D. Friedman. Legal Rules under Economics Syntax. Translated by Yang Xinxin. Beijing: Law Press, 2004: 97.

[5] Roger. A. McCain. Game Theory: Introduction to Strategic Analysis. Translated by Yuan Yijun etc. Beijing: China Machine Press, 2006:30.

[6] Grass. G. Bayer et al. Game Analysis on Laws. Translated by Yan Xuyang, Beijing: Law Press, 1999:2.

[7] Joseph. E. Stiglitz, Carle. E. Walsh. Economics. 3rd Edition. Beijing: China Renmin University Press, 2005: 409. 